\title{
PELATIHAN PENULISAN SURAT DINAS DI DESA LANTO KECAMATAN MAWASANGKA TENGAH KABUPATEN BUTON TENGAH
}

\author{
Suhendi Syam, Dina Komalasari, \\ Yurfiah' ${ }^{1)}$ \\ Fakultas Keguruan dan Ilmu Pendidikan \\ Universitas Muhammadiyah Buton \\ e-mail: syamsuhendi@gmail.com
}

\begin{abstract}
Abstrak
Tujuan dari kegiatan pengabdian masyarakat ini adalah untuk memberikan pelatihan penulisan surat dinas di desa Lanto kecamatan Mawasangka Tengah kabupaten Buton Tengah. Metode yang digunakan dalam pengabdiaan ini berbentuk pelatihan, agar peserta dapat praktik secara langsung setelah mendapatkan materi. Metode dalam menyampaikan materi menggunakan metode ceramah. Selain menggunakan metode ceramah digunakan pula metode diskusi, agar peserta yang kurang memahami materi dapat menanyakan kepada pemateri dan peserta yang lainnya bisa manggapi dan menambahkan. Data dan sumber data yang digunakan dalam pengabdian ini adalah dokumen. Penyaji akan mengumpulkan surat-surat resmi yang dikeluarkan oleh kantor kepala desa Lanto setelah dilaksanakan pengabdian selama 2 hari. Hasil dari kegiatan Pengabdian Masyarakat ini adalah memberikan tata cara penulisan suratmenyurat yang baik. Jika diperhatikan dengan baik penulisan surat desa Lanto kecamatan Mawasangka Tengah Kabupaten Buton Tengah secara umum perlu banyak perbaikan. Perbaikan tersebut meliputi bentuk surat, kop surat, isi surat, kaidah- kaidah kebahasaan pada surat, dan kejelasan instansi. Hal tersebut disebabkan oleh beberapa faktor, yaitu belum adanya editor penulisan surat menyurat, diperlukan sebuah pelatihan penulisan surat menyurat agar tidak terjadi kesalahan dalam penulisan surat-menyurat. Mengingat khalayak sasaran berbagai informasi yang diberikan dapat digunakan untuk pelaksanaan operasional tersebut sehingga para aparatur desa Lanto dapat meningkatkan keterampilan menulis surat yang biasa digunakan dalam urusan kedinasan.
\end{abstract}

Kata Kunci: Desa Lanto, Surat Dinas, dan Pelatihan Penulisan.

\section{A. Pendahuluan}

Bahasa adalah sistem lambang bunyi ujaran yang digunakan untuk berkomunikasi oleh masyarakat pemakainya. Fungsi tersebut digunakan dalam berbagai lingkungan, tingkatan, dan kepentingan yang beraneka ragam (Widjono, 2007: 15). Bahasa seseorang mencerminkan pikirannya. Semakin terampil seseorang berbahasa, semakin cerah dan jelas pula jalan pikirannya (Tarigan, 2008: 1).

Bahasa memiliki peranan yang sangat penting dalam kehidupan manusia. Pentingnya suatu bahasa hampir mencakup segala bidang kehidupan manusia. Segala sesuatu yang 
dirasakan, dialami, dihayati, dan dipikirkan oleh seseorang hanya akan diketahui orang lain jika telah diungkapkan dengan bahasa. Melalui bahasa, manusia berkomunikasi untuk berbagai keperluan dalam kehidupannya, baik secara lisan maupun tulis dan secara langsung maupun tidak langsung serta secara resmi maupun tidak resmi.

Bahasa merupakan alat komunikasi yang sangat penting dalam kehidupan manusia. Dalam kapasitasnya sebagai alat komunikasi bahasa memiliki fungsi yang spesifik, seperti untuk menjalin hubungan dengan orang lain, menyatakan keinginan, memberi informasi dan sebagainya. Tanpa bahasa tentu saja akan sangat sulit bagi manusia untuk menyatakan kamauannya, perasaannya, pendapatnya, atau yang lainnya. Selain untuk berkomunikasi dengan bahasa pun manusia dapat saling memberikan informasi yang dibutuhkan. Apalagi dalam kehidupan bermasyarakat. Dalam pergaulan antarmasyarakat, kita tidak terlepas dari saling memberikan informasi. Informasi itu dapat disampaikan kepada pihak lain dengan melalui bahasa lisan atau bahasa tulis. Informasi melalui bahasa tulis antara lain melalui surat. Surat sebagai sarana komunikasi tertulis mempunyai kelebihan-kelebihan jika dibandingkan dengan alat-alat komunikasi lisan (Darmini, dkk. 2011: 254).

Berbagai faktor membuat manusia sulit melakukan komunikasi secara langsung (lisan), seperti jarak, kesibukan, dan waktu. Oleh karena itu, komunikasi bisa dilakukan secara tidak langsung (tertulis). Salah satu media berkomunikasi dalam bentuk tulisan yang dipergunakan dalam berkomunikasi adalah surat. Surat pada dasarnya dipandang sebagai salah satu jenis sarana berkomunikasi yang sangat penting peranannya, baik secara resmi maupun tidak resmi. Surat adalah secarik kertas atau lebih yang berisi percakapan (bahan komunikasi) yang disampaikan oleh seseorang kepada orang lain, baik atas nama pribadi maupun organisasi/lembaga/instansi (Suryani dkk, 2014: 2). Selanjutnya, Finoza dalam Rahardi, 2008: 11) menyatakan bahwa surat adalah informasi tertulis yang dapat dipergunakan sebagai alat komunikasi tulis yang dibuat dengan persyaratan tertentu yang berlaku untuk surat-menyurat.

Sebagai sarana komunikasi, surat pasti melibatkan dua pihak, yaitu pengirim surat atau penulis surat dan penerima surat. Pengirim surat dapat berupa perseorangan, lembaga, atau pun instansi dan demikian pula halnya dengan penerima surat. Surat dapat dipandang sebagai wakil dari penulisnya. Oleh karena itu, segala sesuatu yang ditulis di dalam surat tersebut mewakili pribadi penulis surat. wujudnya dibedakan menjadi tujuh jenis, yaitu surat terbagi atas surat bersampul, kartu pos, warkat pos, telegram, teleks atau faksimile, memo, dan nota. Surat berdasarkan ruang lingkup sasarannya dibedakan menjadi dua jenis, yaitu surat terbagi atas surat intern dan ekstern (Suparno dan M. Yunus dalam Saddhono dan Slamet, 2014: 187-188). 
Berdasarkan jenis surat di atas terdapat jenis surat dinas. Surat dinas adalah surat yang berisi masalah kedinasan atau bisnis tertentu yang bersifat resmi. Pembuatan surat dinas harus memperhatikan kaidah penulisan surat resmi, seperti kaidah tata bahasa dan ejaan yang benar. Oleh karena itu, sebelum menulis surat penulis harus mempertimbangkan dengan baik susunan kalimat, pilihan kata atau diksi, dan ejaan serta pemakaian tanda baca yang dapat memperjelas maksud surat. Selain itu, penulis surat juga harus menghindari pemakaian kata yang kurang tepat dan memperhatikan pedoman penulisan surat. Kesalahpahaman atau salah pengertian dalam berkomunikasi melalui surat dapat dihindari dengan menulis pesan secara jelas serta diungkapkap dengan benar. Penggunaan bahasa yang tepat dan benar dapat membantu penerima surat memahami maksud dari pengirim surat, serta memiliki pengertian yang sama.

Surat dinas memiliki beberapa fungsi terutama bagi lembaga pemerintahan seperti bukti hitam di atas putih, pengingat, bukti sejarah, pedoman kerja, dan duta perusahaan atau instansi. Fungsi surat sebagai bukti hitam di atas putih, untuk mengantisipasi hal-hal yang tidak diinginkan terkait dengan surat perjanjian. Fungsi surat sebagai pengingat, yaitu untuk kebijakan dan keputusan yang sudah pernah diambil dapat diidentifikasi secara baik sehingga bisa mempermudah

Surat memiliki berbagai jenis berdasarkan tujuan, isi, dan sifat. Surat berdasarkan kepentingan dan pengirimannya dibedakan menjadi tiga jenis, yaitu surat pribadi, dinas, dan niaga. Surat berdasarkan isinya dibedakan menjadi sepuluh jenis, yaitu surat pemberitahuan, surat keputusan, surat perintah, surat permintaan, surat panggilan, surat peringatan, surat laporan, surat pengantar, surat undangan, dan surat lamaran pekerjaan. Surat berdasarkan sifatnya dibedakan menjadi tiga jenis, yaitu biasa, konfidensial (biasa), dan rahasia. Surat berdasarkan banyak sasarannya dibedakan menjadi tiga jenis, yaitu surat biasa, edaran, dan pengumuman. Surat berdasarkan tingkat kepentingannya dibedakan menjadi tiga jenis, yaitu surat biasa, surat kilat, dan surat kilat khusus. Surat berdasarkan wujudnya dibedakan menjadi tujuh jenis, yaitu surat terbagi atas surat bersampul, kartu pos, warkat pos, telegram, teleks atau faksimile, memo, dan nota. Surat berdasarkan ruang lingkup sasarannya dibedakan menjadi dua jenis, yaitu surat terbagi atas surat intern dan ekstern (Suparno dan M. Yunus dalam Saddhono dan Slamet, 2014: 187-188).

Berdasarkan uraian di atas dapat disimpulkan bahwa keberadaan surat dinas di instansi pemerintahan sangatlah penting. Pentingnya surat hampir mencakup segala kegiatan yang ada di instansi pemerintahan. Surat dinas merupakan alat komunikasi di kantor kecamatan maupun kantor lain yang digunakan untuk menyampaikan maksud kepada masyarakat umum ataupun 
instansi pemerintahan lain. Untuk melakukan berbagai kegiatan suatu instansi pemerintahan pasti akan menggunakan surat, misalnya untuk menyampaikan suatu kegiatan kepada masyarakat umum atau pun staf-staf desa. Selain itu, surat juga digunakan untuk melakukan permohonan ataupun lainnya kepada instansi yang lebih tinggi dari instansi tersebut. Misalnya kantor kecamatan akan melakukan perbaikan jalan dan membutuhkan bantuan alat maupun bahan maka kantor kecamatan tersebut akan mengirimkan surat permohonan kepada bupati yang ada di kabupaten.

Surat yang dibuat dan dikeluarkan oleh lembaga pemerintah maupun lembaga swasta seperti kelurahan haruslah sesuai dengan tata aturan yang benar sehingga tujuan yang dituliskan dapat dipahami oleh penerima surat. Di Desa Lanto kami masih menemukan kekeliruan-kekeliruan yang terjadi dalam surat resmi yang dikeluarkan oleh desa. Seperti banyaknya kalimat yang tidak efektif, penggunaan tanda baca atau simbol yang tidak tepat, bahkan tata aturan dalam membuat surat masih kurang dipahami oleh aparat desa. Untuk itu kami tergerak untuk memberikan pelatihan tentang cara penulisan surat resmi pada aparat desa Lanto Kecamatan Mawasangka Tengah Kabupaten Buton Tengah.

Pelatihan merupakan proses secara sistematis mengubah tingkah laku pegawai untuk mencapai tujuan organisasi Rivai (2005: 225). Pelatihan berkaitan dengan keahlian dan kemampuan pegawai untuk melaksanakan pekerjaan saat ini. Pelatihan memiliki orientasi saat ini dan membantu pegawai untuk mencapai keahlian dan kemampuan tertentu agar berhasil dalam melaksanakan pekerjaannya Dengan diadakan pelatihan ini diharapkan dapat memberikan perubahan yang baik bagi aparat desa Lanto. Sehingga surat-surat yang dikeluarkan dapat lebih mudah lagi dipahami oleh masyarakat. Pelatihan dilakukan diawali dengan memberikan teori terlebih dahulu kemudian memberikan kesempatan kepada peserta pelatihan untuk menanyakan materi yang belum dipahami kemudian kegiatan terakhir peserta pelatihan diperintahkan untuk membuat surat resmi sesuai dengan materi yang didapatkan. Selain itu peserta pelatihan diberikan buku panduan penulisan surat dinas.

\section{B. Masalah}

Dari uraian di atas pengabdi dapat mengambil rumusan masalah sebagai berikut, bagaiamanakah pemahaman Aparatur Desa Lanto Kecamatan Mawasangaka Tengah terhadap Penulisan Surat Dinas?

\section{Metode Pelaksanaan}

Kegiatan pengabdian ini dilaksanakan di desa Lanto Kecamatan Mawasangka Tengah Kabupaten Buton Tengah pada bulan Maret 2018. Sasaran pengabdian ini adalah aparat 
desa Lanto, yang berjumlah 11 orang yang semuanya merupakan aparat desa lanto. Bahan dan peralatan yang digunakan dalam pelaksanaan pengabdian yaitu; buku panduan penulisan surat dinas. Dengan buku panduan peserta pelatihan dipandu dalam penulisan surat dinas dengan baik. Power point untuk menyampaikan materi kepada peserta, dan LCD untuk menayangkan materi atau power point yang sudah disiapkan agar peserta dapat memperhatikan lebih mudah.

Metode yang digunakan dalam pengabdiaan ini berbentuk pelatihan, agar peserta dapat praktik secara langsung setelah mendapatkan materi. Metode dalam menyampaikan materi menggunakan metode ceramah. Menurut Sumantri dan Johar (2000: 136) metode ceramah sebagai penyajian pelajaran oleh guru dengan cara memberikan penjelasan secara lisan kepada peserta didik. Selain menggunakan metode ceramah digunakan pula metode diskusi, agar peserta yang kurang memahami materi dapat menanyakan kepada pemateri dan peserta yang lainnya bisa manggapi dan menambahkan.

Data dan sumber data yang digunakan dalam pengabdian ini adalah dokumen. Penyaji akan mengumpulkan surat-surat resmi yang dikeluarkan oleh kantor kepala desa Lanto setelah dilaksanakan pengabdian selama 2 hari. Olahan data yang dilakukan penyaji dengan teknik deskriptif kualitatif dengan studi kasus terpancang (embedded case study rearch) (Purwandri, dkk. 2014: 481).

\section{Pembahasan}

Hasil dari olahan penyaji dari data pengabdian masyarakat yang penyaji laksanakan menghasilkan adanya peningkatan. Kekeliruan-kekeliruan yang terjadi sebelum dilaksanakan pengabdian sudah tidak terjadi kembali. Surat-surat resmi atau dinas yang dibuat telah sesuai dengan ketentuan-ketentuan penulisan surat resmi atau dinas. Pelaksanaan kegiatan berjalan dengan lancar tanpa kendala yang berarti. Peserta pelatihan sangat menerima dengan baik dan antusias mengikuti pelaksanaan pelatihan. Pengabdian ini sangat berdampak baik. Ini dibuktikan dengan adanya perubahan pada penulisan surat dinas yang dibuat oleh kantor kepala desa Lanto Kecamatan Mawasangka Tengah Kabupaten Mawasangka.

Pada awal kegiatan, kepala Desa Lanto, memberikan sambutan sekaligus membuka kegiatan pengabdian masyarakat. Pada sambutannya, Bapak Kepala Desa menghimbau agar para peserta dapat mengikuti kegiatan pelatihan penulisan surat resmi ini dengan baik agar pelatihan surat menyurat ini menambah wawasan ke- ilmuan mengenai cara menulis surat yang baik dan benar. 
Selanjutnya, kami mengucapkan terimakasih kepada kepala desa Lanto yang telah memberikan izin kepada tim pelaksana untuk melakukan kegiatan pengabdian pada masyarakat ini dan mengizinkan tim menggunakan ruangan aula desa sebagai lokasi pelaksanaan kegiatan pelatihan serta menyambut kedatangan kami dengan baik. Dengan diadakannya kegiatan ini, diharapkan dapat membantu aparatur desa dalam menulis surat resmi.

Pada saat melakukan penyuluhan, kami menyampaikan materi mengenai teknik menulis surat yang baik dan benar. Kegiatan penyuluhan ini dilakukan dengan memberikan pe- ngetahuan mengenai syarat-syarat surat, bagaian-bagaian surat, serta keriteria bahasa surat yang baik. Selanjutnya, diadakan sesi tanyajawab, diskusi dan konsultasi untuk menggali dan memaparkan hal-hal yang belum dikuasai dan belum dipahami peserta pelatihan penulisan surat menyurat pemahaman lanjutan terhadap materi yang disampaikan. Ternyata banyak pertanyaan terkait bentuk surat menyurat, format tanda tangan, peletakan stempel, dan bahasa surat yang baik dan benar. Selanjutnya, tim pelaksana mengadakan evaluasi surat beberapa contoh surat keluar dari kantor desa Lanto.

Tim pelaksana melakukan imbauan kepada peserta agar menyiapkan konseptor dan editor setiap akan menulis surat. Hal ini akan meminimalisasi kesalahan dalam menulis surat. Luaran dari kegiatan pengabdian masyarakat ini yakni pengetahuan berupa cara dan teknik dalam menulis surat dan modul yang dilengkapi beberapa contoh surat resmi, baik perbaikan dari surat keluar ataupun dari contoh lainnya. Diharapkan dengan adanya modul yang dilengkapi beberapa contoh peserta dapat menulis surat dengan baik dan benar.

Tujuan dari kegiatan pengabdian masyarakat ini, yaitu memberikan pengetahuan mengenai cara penulisan surat-menyurat bagi bagi aparatur desa Lanto. Hal ini dimaksudkan agar aparat desa memiliki keterampilan menulisan surat-menyurat yang baik. Tim pelaksana pengabdian masyarakat ini dilakukan oleh tiga orang dosen dari Universitas Muhammadiyah Buton. Lokasi pelatihan ini dilakukan aula desa Lanto Kecamatan Maasangka Tengah Kabupaten Buton Tengah. Dipilihnya desa Lanto ini atas dasar beberapa pertimbangan setelah tim pengabdian masyarakat melakukan observasi di lokasi tersebut. Salah satu alasan yang paling mendasar adalah belum adanya konseptor, dan editor penulisan surat resmi pada kedua mitra tersebut.

Pada awal kunjungan tim pengabdian masyarakat adalah membicarakan tujuan, bahan yang akan disampaikan, menentukan hari pelatihan yang ditentukan oleh kedua belah pihak dan meminta beberapa sampel surat keluar. Pihak pertama yaitu aparatur desa Lanto 
meminta adanya pelatihan penulisan surat menyurat resmi. Pihak kedua yaitu tim pengabdian masyarakat memberikan pelatihan surat menyurat resmi dengan metode ceramah, diskusi, dan penugasan. Pelatihan tersebut dapat dilaksanakan dengan baik karena antusias dari para peserta untuk mengikuti pembinaan serta kerja sama yang baik antara kedua belah pihak. Berdasarkan hasil diskusi pada pelatihan surat-menyurat, diperoleh hasil sebagai berikut.

1. Peserta mendapat pengetahuan mengenai pelatihan surat-menyurat yang baik.

2. Peserta dapat bertukar pengalaman dalam menulis surat resmi.

3. Peserta dapat mengembangkan potensinya dalam menulis surat resmi.

Luaran yang dihasilkan dari pelaksanaan pelatihan ini adalah aktivis aparatur desa Lanto mampu dan terampil dalam menulis surat resmi sesuai dengan kaidah kebahasaan yang berlaku. Selain itu, luaran lain yang akan dihasilkan yaitu artikel. Artikel sebagai bentuk publikasi tim mengenai hasil pengabdian pada masyarakat yang akan dicapai. Hal tersebut dilakukan agar hasil yang diperoleh dapat diketahui oleh masyarakat luas, sehingga informasi yang dicapai bermanfaat. Selain itu, luaran yang dihasilkan berupa modul penulisan surat yang disusun langsung oleh tim pelaksana. Modul disusun sebagai bentuk luaran yang dapat dimanfaatkan oleh tim pelaksana untuk pengajaran dan untuk peserta sebagai sarana panduan dalam penulisan surat.

\section{E. Kesimpulan}

Simpulan dari kegiatan Pengabdian Masyarakat ini adalah memberikan tata cara penulisan surat-menyurat yang baik. Jika diperhatikan dengan baik penulisan surat desa Lanto kecamatan Mawasangka Tengah Kabupaten Buton Tengah secara umum perlu banyak perbaikan. Perbaikan tersebut meliputi bentuk surat, kop surat, isi surat, kaidahkaidah kebahasaan pada surat, dan kejelasan instansi. Hal tersebut disebabkan oleh beberapa faktor, yaitu belum adanya editor penulisan surat menyurat, diperlukan sebuah pelatihan penulisan surat menyurat agar tidak terjadi kesalahan dalam penulisan suratmenyurat. Mengingat khalayak sasaran berbagai informasi yang diberikan dapat digunakan untuk pelaksanaan operasional tersebut sehingga para aparatur desa Lanto dapat meningkatkan keterampilan menulis surat yang biasa digunakan dalam urusan kedinasan 


\section{DAFTAR PUSTAKA}

Dardjowidjojo, Soenjono. (2014). Panduan Penulisan Surat. Jakarta: Yayasan Pustaka Obor Indonesia.

Darmini, Wiwik, dkk. (2011). Pelatihan Penulisan Surat Resmi Berbahasa Indonesia di Gabungan Organisasi Wanita (GOW) kabupaten Sukoharjo. Proceeding Seminar Hasil Penelitian dan Pengabdian Kepada Masyarakat Universitas Veteran Bangun Nusantara: Sistem Penjaminan Mutu Penelitian di Perguruan Tinggi. ISBN: 978-60299172-5-3.

Finoza, L. (2006). Aneka Surat Sekretaris dan Surat Bisnis Indonesia. Jakarta: Usaha Mulia.

Fitriyani, Dwi. (2017). Pelatihan Peulisan Surat Dinas Di Pekon Banyu URIP. Jurnal Bagimu Negeri, Volume 1 No 01: 21-29.

Khoiril, Ahmad, dkk. (2018). Penulisan Surat Resmi di Ikatan Remaja Masjid Kelurahan Jatiluhur dan Jatimekar Kecamatan Jatiasih Kota Bekasi. Jurnal PKM-Pengabdian Pada Masyarakat, Volume 01 No 02: 76 - 80.

Malik, Abdul dan Shanty, Isnaini Leo. (2003). Kemahiran Menulis. Pekanbaru: UNRI Press.

Pratiwi, H. A. (2013). Panduan Belajar Korespondensi Bahasa Indonesia. Tangerang: Pustaka Mandiri.

Pramanita, Desi, dkk. (2015). Pengaruh Model Pembelajaran Self Directed Learning Terhadap Kemampuan Menulis Surat Dinas Siswa Kelas VIII SMP Negeri 13 Lubuklinggau. Jurnal Edukasi Musi Rawas Vol 03 No 1: 66-84.

Purwandri, Heni Setya, dkk. (2014). Analisis Kesalahan Berbahasa Indonesia Pada Surat Dinas Kantor Kepala Desa Jladri. Basastra Jurnal Penelitian Bahasa, Sastra Indonesia dan Pengajarannya Volume 1 Nomor 3: (478-489).

Rivai, Veithzal. (2005). Manajemen Sumber Daya Manusia Untuk Perusahaan Dari Teori ke Praktik. Jakarta: PT. Raja Grafindo Persada.

Sartuni, dkk. (2016). Implementasi Bahasa Akademik. Tanggerang: Pustaka Mandiri.

Sumantri M dan Johar Permana. (2000). Strategi Belajar Mengajar. Jakarta: Dirjen Dikti Depdikbud. 